\title{
KEDUDUKAN HAK CIPTA DALAM MEWUJUDKAN HAK EKONOMI SEBAGAI UPAYA PERLINDUNGAN TERHADAP INTELLECTUAL PROPERTY RIGHTS
}

\author{
Indah Sari ${ }^{0}$
}

\begin{abstract}
This research aimed at analysing how copyrights could bring about economic rights for innovators and authors. In addition of generating economic rights, copyrights also protecting intellectual property rights. As we know, intellectual property rights is rights obtained from one's thoughts or ideas, and it has economical values for the innovator and/or author. As it consequence, people required to get license from and grant royalty to the innovator and/or author when they need to gain further these economic values. This condition also valid to the copyrights as contained in law no. 28 of 2014 on Copyrights. Research here focused on economic rights of copyrights; what kind of economic advantages would gained by the innovator and/or author of his/her creation
\end{abstract}

Keywords: Copyrights, Economic Rights, Intellectual Property Rights

\section{PENDAHULUAN}

Indonesia sebagai negara kepulauan memiliki keanekaragaman seni dan budaya yang sangat kaya. Hal itu sejalan dengan keanekaragaman etnik, suku bangsa, dan agama yang secara keseluruhan merupakan potensi nasional yang perlu dilindungi. Kekayaan seni dan budaya itu salah satu sumber dari karya intelektual yang dapat dan perlu dilindungi oleh undang-undang.

Kekayaan itu tidak semata-mata untuk seni dan budaya itu sendiri, tetapi dapat dimanfaatkan untuk meningkatkan kemampuan di bidang perdagangan dan industri yang melibatkan para Pencipta. Dengan demikian, kekayaan seni dan budaya yang dilindungi itu dapat meningkatkan kesejahteraan tidak hanya bagi para Penciptanya saja, tetapi juga bagi bangsa dan negara. ${ }^{1}$ Kekayaan seni, budaya dan juga teknologi yang merupakan karya intelektual manusia haruslah mendapatkan payung hukum yang jelas dan tegas.

Hukum tidak dapat berkembang tanpa dukungan ekonomi yang tumbuh, tetapi, perekonomian tidak akan tumbuh dan berkembang jika hukum tidak mampu menjamin keadilan yang pasti dan kepastian yang adil. Demikian pula tanpa stabilitas politik dan derajat kebebasan yang teratur, dinamika perekonomian tidak akan

\footnotetext{
1 Lihat lebih lanjut Penjelasan Umum Undang-Undang Nomor 19 Tahun 2002 tentang Hak Cipta pada Kitab Undang-Undang HaKI (Hak Kekayaan Intelektual), Fokusmedia, Bandung, 2013, hal.2.
} 
berkembang. Politik menyediakan tatanan kehidupan bermasyarakat dan bernegara, sekaligus membuka ruang untuk kebebasan. pagar atau mengikuti rambu-rambu hukum yang menjamin keteraturan. ${ }^{2}$ Begitu juga dengan keberadaaan Intellectual Property Rights.

Intellectual Property Rights atau Hak atas Kekayaan Intelektual (HaKI) atau HKI pada prinsipnya adalah hasil pemikiran, kreasi dan desain seseorang yang oleh hukum diakui dan diberikan hak atas kebendaan sehingga hasil pemikiran, kreasi dan desain tersebut dapat diperjual belikan. Dengan demikian, seseorang yang memiliki Hak Kekayaan Intelektual dapat diberikan royalti atau pembayaran oleh orang lain yang memanfaatkan atau menggunakan nakan Hak Kekayaan Intelektual tersebut. ${ }^{3}$

Dari sekian banyak ruang lingkup Hak atas Kekayaan Intektual (HaKI) salah satunya adalah keberadaan Hak Cipta. Hak Cipta itu sendiri merupakan Hak Eksklusif Pencipta yang timbul secara otomatis berdasarkan prinsip deklaratif setelah suatu Ciptaan diwujudkan dalam bentuk nyata tanpa mengurangi pembatasan sesuai dengan ketentuan peraturan perundang-

${ }^{2}$ Jimly Asshiddiqie, Konstitusi Ekonomi, Penerbit KOMPAS, Jakarta, 2010, hal.16.

3 Zaeni Ashadie, Hukum Bisnis Prinsip Dan

Pelaksanaannya di Indonesia, Rajawali Pers, Jakarta, 2012, hal.215
Akan tetapi kebebasan yang dikembangkan tersebut tentulah harus berada dalam pagar-

undangan. ${ }^{4}$ Keberadaan Hak Cipta haruslah mendapatkan dasar hukum yang jelas dan tegas agar si Pencipta dengan karya Ciptaannya memang dilindungi oleh Undang-Undang. Maka seseorang atau beberapa orang dengan tidak mudah mengambil, atau meniru Ciptaan si Pencipta tadi. Inilah kegunaan hukum bagi keteraturan ekonomi. Hak Cipta itu sendiri secara otomatis mengandung Hak Ekonomi atau nilai ekonomi bagi si Penciptanya selain Hak Moral yang melekat pada Hak Cipta. Si Pencipta bebas dan berhak untuk menikmati nilai ekonomi/keuntungan ekonomi dari Ciptaannya, dan jika orang lain ingin menikmati nilai ekonomi tersebut tentu ada aturan main yang jelas sebagaimana dirumuskan dalam UndangUndang Nomor 28 Tahun 2014 tentang Hak Cipta.

Adapun dasar pertimbangan dikeluarkannya Undang-Undang Nomor 28 Tahun 2014 tentang Hak Cipta adalah ${ }^{5}$ : bahwa Hak Cipta merupakan kekayaan intelektual di bidang ilmu pengetahuan, seni dan sastra yang mempunyai peranan

\footnotetext{
${ }^{4}$ Lihat Pasal 1 ayat (1) Undang-Undang Nomor 28 Tahun 2014 tentang Hak Cipta.

${ }^{5}$ Lihat lebih lanjut dasar pertimbangan diundangkannya

Undang-Undang Nomor 28 Tahun 2014 Tentang Hak Cipta
} 
strategis dalam mendukung pembangunan bangsa dan memajukan kesejahteraan umum sebagaimana diamanatkan oleh UndangUndang Dasar Negara Republik Indonesia. Karena perkembangan ilmu pengetahuan, teknologi, seni dan sastra sudah demikian pesat sehingga memerlukan peningkatan perlindungan dan jaminan kepastian hukum bagi Pencipta, Pemegang Hak Cipta, dan pemilik Hak Terkait.

Berdasarkan uraian diatas akhirnya penulis tertarik untuk meneliti lebih lanjut ruang lingkup Hak Cipta dan seberapa besar Kedudukan Hak Cipta dalam mewujudkan Hak Ekonomi. Akhirnya penulis mengambil judul penelitian ini "KEDUDUKAN HAK CIPTA DALAM MEWUJUDKAN HAK EKONOMI SEBAGAI UPAYA PERLINDUNGAN TERHADAP INTELLECTUAL PROPERTY RIGHTS"

\section{RUMUSAN MASALAH}

a. Apa saja ruang lingkup dari Hak Cipta?

b. Bagaimana kedudukan Hak Cipta dalam mewujudkan Hak Ekonomi sebagai upaya perlindungan terhadap Intellectual Property Rights?

\section{METODOLOGI PENELITIAN}

Menurut Soerjono Soekamto, metode adalah proses, prinsip-prinsip dan tata cara memecahkan suatu masalah, sedangkan penelitian adalah pemeriksaan secara hatihati, tekun dan tuntas terhadap suatu gejala untuk menambah pengetahuan manusia. Maka metode penelitian dapat diartikam sebagai proses, prinsip-prinsip dan tatacara untuk memecahkan masalah yang dihadapi dalam melakukan penelitian. ${ }^{6}$

Adapun jenis penelitian ini adalah penelitian yuridis normatif maksudnya adalah penelitian yang berdasarkan sumber data sekunder saja yakni peraturan perundang-undangan, keputusan-keputusan pengadilan, teori-teori hukum, konsep hukum dan pandangan sarjana hukum yang terkemuka. $^{7}$ Dalam teknik analisis data penulis menggunakan metode kualitatif yaitu data yang telah dikumpul kemudian diolah dan dianalisis dengan metode kualitatif. Penggunaan metode kualitatif karena data yang diolah adalah data sekunder dengan deskriptif analisis. Melakukan analisis hanya sampai taraf deskripsi saja yaitu menganalisis dan menyajikan fakta secara sistematis sehingga lebih mudah dipahami dan kemudian dapat ditarik suatu kesimpulan.

\footnotetext{
${ }^{6}$ Soerjono Soekamto, Pengantar Penelitian Hukum, UI Press, Jakarta, 1986, hal.6

7 Suratman, Philips Dillah, Metode Penelitian Hukum, Alfabeta, Bandung, 2012, hal.11
} 


\section{TUJUAN PENELITIAN}

Adapun tujuan dari penelitian ini adalah:

1. Untuk mengkaji dan menganalisis lebih dalam apa yang dimaksud dengan Hak Cipta, ruang lingkup Hak Cipta, subjek Hak Cipta dan dasar hukum Hak Ciptaa

2. Untuk meneliti kajian yang lebih dalam lagi bagaimana peranan Hak Cipta dalam mewujudkan Hak Ekonomi bagi Pencipta dalam upaya melakukan perlindungan terhadap Intellectual Property Rights (Hak atas Kekayaaan Intelektual), dan juga akan dikaji Hak-Hak Ekonomi apa saja yang diatur dalam Undang-Undang Nomor 28 Tahun 2014 Tentang Hak Cipta.

\section{HASIL DAN PEMBAHASAN}

\section{A. PERAN INDONESIA DALAM TRIPS SEBAGAI AGENDA WTO}

Sistem ekonomi pasar dengan cirinya Persaingan Sehat (fair competition) merupakan tujuan agenda global WTO (World Trade Organization). Indonesia sebagai salah satu anggota WTO secara proaktif mendukung pencapaian Persaingan Sehat yang diyakini merupakan suatu persyaratan mutlak untuk menstimulasi kegiatan ekonomi. Persaingan Sehat dipercaya mampu menjadi penggerak kegiatan ekonomi karena hal tersebut menjamin kemungkinan kebebasan yang lebih luas dari tindakan bagi semua. Perlindungan Hak Kekayaan Intelektual atau Intellectual Property Rights sebagai hak kepemilikan pribadi (private property) menjadi elemen yang krusial dari kebijakan perdagangan proses industri. Guna memahami gejala dan aspek ekonomi yang terkait dengan kebijakan perdagangan serta mengkaitkannya dengan struktur internasional atau secara khusus dinamika hubungan ekonomi internasional, maka perlindungan Hak Kekayaan Intelektual tidak dapat diabaikan. ${ }^{8}$

Perhatian terhadap Hak Kekayaan Intelektual dalam perdagangan internasional sangat besar. Hal ini terbukti dengan adanya perundingan di Jenewa pada September 1990 Intellectual Property in Business Briefing mendiskusikan masalah tersebut, yang kini dikenal dengan TRIPs atau Trade Related Aspects of Intellectual Property Rights (Aspek-Aspek Dagang yang terkait dengan Hak Kekayaan Intelektual). Menurut penjelasan Undang-Undang Nomor 7 tahun 1994 tentang pengesahan Agreement Establising the World Trade Organization

\footnotetext{
8 Nasution, Rahmi Jened Parinduri, Interface Hukum Kekayaan Intelektual dan Hukum Persaingan (Penyalahgunaan HKI), Rajawali Pers, Jakarta, 2013, 52-54
} 
(Persetujuan Pembentukan Organisasi Perdagangan Dunia) perundingan ini bertujuan untuk:

1. Meningkatkan perlindungan terhadap Hak Kekayaan Intelektual dari produkproduk yang diperdagangkan

2. Menjamin prosedur pelaksanaan Hak Kekayaan Intelektual yang tidak menghambat kegiatan perdagangan.

3. Merumuskan aturan serta disiplin mengenai pelaksanaan perlindungan terhadap Hak Kekayaan Intelektual.

4. Mengembangkan prinsip, aturan, dan mekanisme kerjasama internasional untuk menangani perdagangan barangbarang hasil pemalsuan atau pembajakan atas Hak atas Kekayaan Intelektual. ${ }^{9}$

Trade Related Aspects of Intellectual Property Rights sendiri menekankan sistem Hak Kekayaan Intelektual dimaksud untuk "contribute to the promotion of technology, to the mutual advantage of producers and users of technological knowledge an in a manner conductive to social and ecomonic welfare, and to a balance of rights and obligations". Kesemuanya tetap memperhatikan berbagai upaya yang telah

${ }^{9}$ Muhammad Djumhana, R. Djubaedillah, Hak Milik Intelektual Sejarah, Teori, dan Praktiknya di Indonesia, PT. Citra Aditya Bakti, Bandung, 2014, hal.4-5 dilakukan oleh World Intellectual Property Organization (WIPO). ${ }^{10}$

Gambaran di atas menunjukan bahwa Hak Kekayaan Intelektual telah menjadi bagian terpenting suatu negara untuk menjaga keunggulan industri perdagangannya, diakui bahwa pertumbuhan ekonomi suatu negara banyak bergantung pada perdagangannya, yang pada akhirnya ditentukan pula oleh keunggulan komparatif yang dimilkinya. Sementara itu keunggulan komparatif banyak bergantung pada kemampuan teknologinya, yang salah satu unsurnya adalah pada bidang cakupan Kekayaan Intelektual. Jadi, Kekayaan Intelektual marupakan salah satu bagian sangat strategis dalam kegiatan ekonomi suatu negara pada saat ini. ${ }^{11}$

Berdasarkan uraian di atas sebagai sebuah Negara besar dan mempunyai pergaulan internasional yang luas akhirnya Indonesia telah ikut serta dalam pergaulan masyarakat dunia dengan menjadi anggota dalam Agreement Establishing the World Trade Organization (Persetujuan Pembentukan Organisasi Perdagangan Dunia) yang mencakup pula Agreement on Trade Related Aspects of Intellectual Property Rights (Persetujuan tentang AspekAspek Dagang Hak Kekayaan Intelektual, selanjutnya disebut TRIPs, melalui Undang-

${ }^{10}$ Ibid, hal.5

${ }^{11}$ Ibid, hal.5 
Undang Nomor 7 Tahun 1994. Selain itu Indonesia juga meratifikasi Berne Convention for the Protection of Artistic and Literary Works (Konvensi Berne tentang Perlindungan Karya Seni dan Sastra) melalui Keputusan Presiden Nomor 18 Tahun 1997 dan World Intellectual Property Organization Copyrights Treaty (Perjanjian Hak Cipta WIPO/World Intellectual Property Organization), selanjutnya disebut WCT, melalui Keputusan Presiden Nomor 19 Tahun 1997. ${ }^{12}$

\section{B. PERLINDUNGAN} TERHADAP INTELLECTUAL PROPERTY

\section{RIGHTS}

Hak Kekayaan Intelektual atau disingkat dengan "HKI" atau akronim "HaKI" adalah padanan kata yang biasa digunakan untuk Intellectual Property Rights (IPR) yakni hak yang timbul bagi hasil olah pikir otak yang menghasilkan suatu produk atau proses yang berguna untuk manusia. Pada intinya HKI atau HaKI adalah hak untuk menikmati secara ekonomis hasil dari suatu kreativitas intelektual. Objek yang diatur dalam HKI

\footnotetext{
12 Lihat lebih lanjut Penjelasan Umum Undang-Undang tentang Hak Cipta Nomor 19 Tahun 2002 dalam Kitab Undang-Undang HaKI (Hak Kekayaan Intelektual) Fokus Media, Bandung, 2013, hal. 2 dan 3. Baca juga UndangUndang Nomor 7 Tahun 1994 serta Keputusan Presiden Nomor 18 Tahun 1997.
}

adalah karya-karya yang timbul atau lahir karena kemampuan intelektual manusia. ${ }^{13}$

Hak Kekayaan Intelektual ini (Intellectual Property Rights (IPR) baru ada jika kemampuan intelektual manusia telah membentuk sesuatu, baik yang bisa dilihat, didengar, dibaca, maupun digunakan secara praktis. David I. Bainbridge mengatakan bahwa:

"Intellectual Property is the collective nama given to legal rights which protect the product of the human intellect. ${ }^{14}$ The term intellectual property seem to be the best available to cover that body of legal rights which arise from mental and artistic endeavour." $" 15$

Dari uraian diatas kita dapat menyimpulkan bahwa Hak Kekayaan Intelektual ini merupakan hak yang berasal dari hasil kegiatan kreatif suatu kemampuan daya pikir manusia yang diekspresikan kepada kalayak umum dalam berbagai bentuknya, yang memiliki manfaat serta berguna dalam menunjang kehidupan manusia, juga memiliki nilai ekonomi. Bentuk nyata dari kemampuan karya intelekktual tersebut

13 Direktorat Jenderal Hak Kekayaan Intelektual, Buku Panduan Hak Kekayaan Intelektual, Tangerang, 2005, hal.3 ${ }^{14}$ David I. Bainbridge, 1990, Computers and the Law, Cetakan Pertama, London: Pitman Publishing. H.7 ${ }^{15}$ John F. Williams, 1986, A Manager's Guide to Patent, Trade Marks \& Copyright, Cetakan Pertama, London: Kogan Page, h.11 
bisa dibidang teknologi, ilmu pengetahuan, ataupun seni dan sastra. ${ }^{16}$

Hak kekayaan intelektual adalah hak kebendaan, hak atas sesuatu benda yang bersumber dari hasil kerja otak, hasil kerja rasio. Hasil dari pekerjaan rasio manusia yang bernalar. Hasil kerja itu berupa benda immateril. Benda yang tidak berwujud. Kita ambil misalnya karya cipta lagu. Untuk menciptakan alunan nada (irama) diperlukan pekerjaan otak. Hasil kerja otak dirumuskan sebagai intelektualitas. Begitulah ketika irama lagu tadi tercipta berdasarkan hasil kerja otak, ia dirumuskan sebagai Hak atas Kekayaan Intelektual (Intellectual Property Rights). Berbeda misalnya hasil kerja fisik, petani mencangkul, menanam menghasilkan buah-buahan. Buah-buahan tadi adalah hak milik juga tetapi hak milik materil. Hak milik atas benda yang berwujud. ${ }^{17}$

Jika ditelusuri lebih lanjut Hak atas Kekayaan Intelektual sebenarnya merupakan bagian dari benda yang tidak berwujud (benda immateril). Benda dalam kerangka hukum perdata dapat diklasifikasikan ke dalam berbagai kategori, salah satu diantara kategori itu, adalah pengelompokan benda ke dalam klasifikasi benda berwujud dan benda yang

\footnotetext{
${ }^{16}$ Muhammad Djumhana, R. Djubaedillah, Op.Cit, 2014, hal.17-18

${ }^{17}$ H. O.K.Saidin, Aspek Hukum Hak Kekayaan Intelektual (Intellectual Property Rights), Rajawali Pers, Jakarta, 2004, hal. 9-10
}

tidak berwujud ${ }^{18}$. Untuk hal ini dapat dilihat batasan benda yang dikemukan dalam pasal 499 KUH Perdata ${ }^{19}$, yang berbunyi : benda ialah tiap-tiap barang dan tiap-tiap hak yang dapat dikuasai oleh Hak Milik. ${ }^{20}$

Bagaimanakah sistem HKI? Sistem HKI merupakan hak privat (private rights). Disinilah ciri khas HKI. Seseorang bebas untuk mengajukan permohonan atau mendaftarkan karya intelektualnya atau tidak. Hak eksklusif yang diberikan Negara kepada individu pelaku HKI (inventor, pencipta, pendesain dan sebagainya), tiada lain dimaksudkan sebagai penghargaan atas hasil karya (kreativitasnya) dan agar orang lain terangsang untuk dapat lebih lanjut mengembangkannya lagi. Sehingga dengan sistem HKI tersebut kepentingan masyarakat ditentukan melalui mekanisme pasar. Disamping itu sistem HKI menunjang diadakannya sistem dokumentasi yang baik atas segala bentuk kreativitas manusia sehingga kemungkinan dihasilkannya teknologi atau hasil karya lainnya yang sama dapat dihindar/cegah. Dengan dukungan dokumentasi yang baik tersebut, diharapakan masyarakat dapat memanfaatkannya dengan maksimal untuk keperluan hidupnya atau

${ }^{18}$ Baca Salim H, Pengantar Huku Perdata Tertulis (BW), Sinar Grafika, Jakarta. 2005 Baca tentang "Hukum Benda"hal 89-110.

${ }^{19}$ Lihat lebih lanjut pasal 499 Kitab Undang-Undang Hukum Perdata

${ }^{20}$ H. O.K Saidin, Op.Cit, 2004, hal. 11 
mengembangkannya lebih lanjut untuk memberikan nilai tambah yang lebih tinggi lagi. 21

Adapun pengelompokan Hak atas Kekayaan Intelektual (Intellectual Property Rights) adalah sebagai berikut: ${ }^{22}$

1. Hak Cipta (Copy Rights)

2. Hak Milik (baca: hak kekayaan) Perindustrian (Industrial Property Rights)

Hak Cipta sebenarnya dapat lagi diklasifikasikan ke dalam dua bagian yaitu:

1. Hak Cipta dan

2. Hak yang berkaitan (bersempadan) dengan Hak Cipta (neighbouring rights)

Selanjutnya hak atas kekayaan perindustrian dapat diklasifikasikan lagi menjadi:

1. Patent (Paten)

2. Utility Models (Model Rancang Bangun) atau dalam hukum Indonesia dikenal dengan istilah paten sederhana (simple patent)

3. Industrial Design (Desain Industri)

4. Trade Merk (Merek Dagang)

5. Trade Names ( Nama Niaga atau Nama Dagang)

6. Indication of Source or Appelation of Origin (Sumber tanda atau sebutan)

Pengelompokan hak atas kekayaan perindustrian seperti tertera diatas

${ }^{21}$ Direktorat Jenderal Hak Kekayaan Intelektual, Op.Cit, 2005, hal.3

${ }^{22}$ H.O.K Saidin, Op.Cit, 2004, hal.13-15. didasarkan pada Convention Establising The World Intellectual Property Organization. Dalam beberapa literatur bidang kekayaan perindustrian yang dilindungi tersebut masih ditambah lagi beberapa bidang lain yaitu: trade secret, service mark, dan unfair competition protection.Sehingga hak atas kekayaan perindustrian itu dapat diklasifikasikan sebagai berikut:

1. Patent

2. Utility Models

3. Industrial Designs

4. $\quad$ Trade Secrets

5. Trade Marks

6. Service Marks

7. Trade Names or Commercial Names

8. Appelations of Origin

9. Indications of Origin

10. Unfair Competition Protection.

Berdasarkan kerangka WTO/TRIPs (World Trade Organization/Trade Related Aspects of Intellectual Property Rights) ada dua bidang lagi yang perlu ditambahkan yakni:

1. Perlindungan Varietas Baru Tanaman

2. Integrated Circuits (rangkaian elektronika terpadu).

Dari perkembangan yang ada kini pengaturan Hak Kekayaan Intelektual menempatkan undang-undang tidak sematamata bersifat tambahan, tetapi juga pembuat 
undang-undang telah bermaksud untuk memberikan sutu ketentuan yang lebih bersifat memaksa. Namun pengaturan tersebut masih bertumpu pada sifat asli yang ada pada Hak Kekayaan Intelektual tersebut, diantaranya: ${ }^{23}$

a. Mempunyai jangka waktu terbatas Dalam arti setelah masa perlindungannya, Ciptaan (Penemuan) tersebut akan menjadi milik umum. Namun ada pula yang setelah habis masa perlindungannya bisa diperpanjang terus, misalnya Hak Merek, tetapi ada juga yang perlindungannya hanya bisa diperpanjang satu kali dan jangka waktunya tidak sama lamanya dengan jangka waktu perlindungan pertama, contoh Hak Paten.

b. Bersifat eksklusif dan mutlak

Maksudnya bahwa hak tersebut dapat dipertahankan terhadap siapapun. Yang mempunyai hak itu dapat menuntut terhadap pelanggaran yang dilakukan oleh siapapun. $\mathrm{Si}$ pemilik/pemegang Hak Kekayaan Intelektual mempunyai suatu hak monopoli, yaitu dia dapat mempergunakan haknya dengan melarang siapapun tanpa persetujuannya membuat ciptaan/penemuan ataupun menggunakannya.

c. Bersifat Mutlak yang bukan kebendaan

${ }^{23}$ Muhammad Djumhana, R Djubaedillah, Op.Cit, 2014. hal. 19-20
Adapun prinsip-prinsip yang terkandung dalam Hak atas Kekayaan Intelektual (Intellectual Property Rights) adalah: ${ }^{24}$

a. Prinsip keadilan (the principle of natural justice)

Pencipta sebuah karya atau orang lain yang bekerja membuahkan hasil dari kemampuan intelektualnya, wajar memperoleh imbalan. Imbalan tersebut dapat berupa materi ataupun bukan materi, seperti adanya rasa aman karena dilindungi dan diakui atas hasil karyanya.

b. Prinsip ekonomi (the economic argument)

Prinsip ekonomi Hak Kekayaan Intelektual ini merupakan hak yang berasal dari hasil kegiatan kreatif suatu kemampuan daya pikir manusia yang diekpresikan kepada khalayak umum dalam berbagai bentuk, yang memilki manfaat serta berguna dalam menunjang kehidupan manusia. Hak Kekayaan Intelektual merupakan suatu bentuk kekayaan bagi pemiliknya. Dari kepemilikannya seseorang akan mendapatkan keuntungan, misalnya dalam bentuk pembayaran royalty atau technical fee.

c. Prinsip kebudayaan (the culture argument)

Kita mengonsepsikan bahwa karya manusia itu pada hakikatnya bertujuan untuk

${ }^{24}$ Ibid, hal. 21-22. 
memungkinkannya hidup. Selanjutnya dari karya itu pula akan timbul suatu gerak hidup yang harus menghasilkan lebih banyak karya lagi. Dengan konsepsi demikian maka pertumbuhan dan perkembangan ilmu pengetahuan, seni, dan sastra sangat besar artinya bagi peningkatan taraf kehidupan, peradaban dan martabat manusia.

d. Prinsip sosial (the social argument)

Hak apapun yang diakui oleh hukum dan diberikan kepada perseorangan atau kepada persekutuan atau kesatuan lain, tidak boleh diberikan semata-mata untuk memenuhi kepentingan perseorangan, persekutuan atau kesatuan itu saja, tetapi juga pemberian hak kepada perseorangan, persekutuan/kesatuan itu diberikan dan diakui oleh hukum. Hal ini disebabkan dengan diberikannya hak tersebut kepada perseorangan, persekutuan atau kesatuan hukum itu, kepentingan seluruh masyarakat akan terpenuhi.

\section{RUANG LINGKUP HAK CIPTA}

Hak Cipta Sebagai Hak Kebendaan

Sebelum kita mengkaji lebih jauh tentang keberadaan Hak Cipta sebagai Hak Kebendaan, maka ada baiknya jika terlebih dahulu kita uraikan apa sebenarnya yang dimaksud dengan Hak Kebendaan. Dalam bahasa Belanda Hak Kebendaan ini disebut zakelijk recht. Prof. Sri Soedewi Masjchoen Sofwan, memberikan rumusan tentang Hak
Kebendaan yakni: "hak mutlak atas suatu benda dimana hak itu memberikan kekuasaan langsung atas suatu benda dan dapat dipertahankan terhadap siapapun". Rumusan bahwa Hak Kebendaan itu adalah hak mutlak yang juga berarti hak absolut yang dapat pertentangkan dengan hak relatif, hak nisbi atau biasanya disebut juga persoonlijk atau hak perorangan. Hak yang disebut terakhir ini hanya dapat dipertahankan terhadap orang tertentu, tidak terhadap semua orang seperti hak kebendaan. ${ }^{25}$

Ada beberapa ciri pokok yang membedakan hak kebendaan dengan hak relatif atau perorangan yaitu: ${ }^{26}$

1. Merupakan hak yang mutlak, dapat dipertahankan terhadap siapapun juga

2. Mempunyai zaaksgevolg atau droit de suite (hak yang mengikuti). Artinya hak itu terus mengikuti bendanya dimanapun juga (dalam tangan siapapun juga) benda itu berada. Hak itu terus saja mengikuti orang yang mempunyainya.

3. Sistem yang dianut dalam hak kebendaan dimana terhadap yang lebih dahulu terjadi mempunyai kedudukan dan tingkat yang lebih tinggi dari pada yang terjadi kemudian.

4. Mempunyai sifat droit de preference (hak yang didahulukan)

${ }^{25}$ H. OK. Saidin, Op.Cit, 2004, hal. 48-49

${ }^{26}$ Ibid, ha.l 49 
5. Adanya apa yang dinamakan gugat kebendaan

6. Kemungkinan untuk dapat memindahkan hak kebendaan itu dapat sepenuhnya dilakukan.

Hak Cipta sebagai Hak Kekayaan Immateril

Yang dimaksud dengan hak kekayaan immateril adalah suatu hak kekayaan yang objek haknya adalah benda tidak berwujud (benda tidak bertubuh). Dalam hal ini banyak yang dapat dijadikan objek hak kekayaan yang termasuk dalam cakupan benda tidak bertubuh. Misalnya, hak tagihan, hak yang ditimbulkan dari penerbitan surat-surat berharga, hak sewa dan lain-lain sebagainya. Hak kekayaan immateril dirumuskan semua benda yang tidak dapat dilihat atau diraba dan dapat dijadikan objek hak kekayaan adalah merupakan hak kekayaan immateril. ${ }^{27}$

Jika kita ingin memastikan tempat atau kedudukan Hak Cipta itu sebagai hak kekayaan immateril maka ada baiknya kita lihat dulu rumusan pasal $499 \mathrm{KUH}$ Perdata. ${ }^{28}$ Pasal ini secara implisit (tersirat) dan menunjukkan bahwa Hak Cipta itu dapat digolongkan sebagai benda yang dimaksud oleh pasal tersebut. Pasal 499 KUH Perdata memberikan batasan tentang rumusan benda, menurut pasal tersebut

\footnotetext{
${ }^{27}$ Ibid, hal. 52

${ }^{28}$ Baca lebih lanjut Pasal 499 Kitab Undang-Undang Hukum (KUH) Perdata
}

bahwa: menurut paham undang-undang yang dinamakan benda ialah tiap-tiap barang dan tiap-tiap hak yang dapat dikuasai menjadi objek kekayaan (property) atau hak milik. Rumusan ini akan menempatkan Hak Cipta sebagai hak yang merupakan bagian dari benda. Hak Cipta menurut rumusan ini dapat dijadikan objek Hak Milik, oleh karena itu, ia memenuhi kriteria pasal 499 KUH Perdata. Si Pemegang Hak Cipta dapat menguasai Hak Cipta sebagai Hak Milik. ${ }^{29}$

Dasar Hukum Hak Cipta

Adapun peraturan Hak Cipta yang pernah berlaku di Indonesia tertuang dalam: a. Undang-Undang Nomor 6 Tahun 1982 tentang Hak Cipta

b. Undamg-Undang Nomor 7 Tahun 1987 tentang Perubahan atas Undang-Undang Nomor 6 Tahun 1982 tentang Hak Cipta

c. Undang-Undang Nomor 12 Tahun 1997 tentang Perubahan atas Undang-Undang Nomor 6 Tahun 1982 tentang Hak Cipta sebagaimana telah diubah dengan UndangUndang Nomor 7 Tahun 1987.

d. Undang-Undang Nomor 19 Tahun 2002 tentang Hak Cipta.

e. Undang-Undang Nomor 28 Tahun 2014 tentang Hak Cipta.

Apa itu Hak Cipta?

${ }^{29}$ H. OK. Saidin, Op.Cit, hal. 52-53 
Sebagaimana yang dirumuskan dalam Undang-Undang Nomor 28 Tahun 2014 tentang Hak Cipta bahwa Hak Cipta adalah Hak Eksklusif Pencipta yang timbul secara otomatis berdasarkan prinsip deklaratif setelah suatu Ciptaan diwujudkan dalam bentuk nyata tanpa mengurangi pembatasan sesuatu dengan ketentuan peraturan perundang-undangan.

Hak Cipta terdiri atas Hak Ekonomi (Economic Rights) dan Hak Moral (Moral Rights). Hak Ekonomi adalah Hak untuk mendapatkan manfaat ekonomi atas Ciptaan serta produk terkait. Hak Moral adalah Hak yang melekat pada diri Pencipta atau Pelaku yang tidak dapat dihilangkan atau dihapus tanpa alasan apapun, walaupun Hak Cipta atau Hak Terkait telah dialihkan,

Pencipta adalah seorang atau beberapa orang yang secara sendiri-sendiri atau bersama-sama menghasilkan suatu ciptaan yang bersifat khas dan pribadi.

Ciptaan adalah setiap hasil karya cipta dibidang ilmu pengetahuan, seni dan sastra yang dihasilkan atas inspirasi, kemampuan, pikiran, imajinasi, kecekatan, keterampilan, atau keahlian yang diekspresikan dalam bentuk nyata.

Pemegang Hak Cipta adalah Pencipta sebagai Pemilik Hak Cipta, pihak yang menerima hak tersebut secara sah dari Pencipta, atau pihak lain yang menerima lebih lanjut dari pihak yang menerima tersebut secara sah.

Ciptaan yang dilindungi oleh Hak Cipta menurut Undang-Undang Nomor 29 Tahun 2014 tentang Hak Cipta. ${ }^{30}$

Adapun Ciptaan yang dilindungi meliputi Ciptaan dalam bidang ilmu pengetahuan, seni, dan sastra, terdiri atas:

a. buku, pamflet, perwajahan karya tulis yang diterbitkan, dan semua hasil karya tulis lainnya.

b. Ceramah, kuliah, pidato, dan Ciptaan sejenis lainnya.

c. Alat peraga yang dibuat untuk kepentingan pendidikan dan ilmu pengetahuan

d. Lagu dan/atau musik dengan atau tanpa teks.

e. Drama, drama musikal, tari, koreografi, pewayangan dan pantomim

f. Karya seni rupa dalam segala bentuk seperti lukisan, gambar, ukiran, kaligrafi, seni pahat, patung atau kolase.

g. Karya seni terapan

h. Karya arsitektur

i. Peta

j. Karya seni batik atau seni motif lain

k. Karya Fotografi

1. Potret

m. Karya Sinematografi

\footnotetext{
${ }^{30}$ Baca lebih lanjut Undang-Undang Nomor 28 Tahun 2014 tentang Hak Cipta
} 
n. Terjemahan, tafsir, saduran, bunga rampai, basis data, adaptasi, aransemen, modifikasi, dan karya lain hasil transformasi.

o. Terjemahan, adaptasi, aransemen, tranformasi, atau modifikasi ekspresi budaya tradisional.

p. Kompilasi Ciptaan atau data, baik dalam format yang dapat dibaca dengan Program Komputer maupun media lainnya.

q. Kompilasi ekspresi budaya tradisional selama kompilasi tersebut merupakan karya yang asli

r. Permainan video

s. Program Komputer.

Hasil Karya yang Tidak Dilindungi

oleh Hak Cipta.Hasil karya yang tidak

dilindungi oleh Hak Cipta meliputi:

a. Hasil Karya yang belum diwujudkan dalam bentuk nyata

b. Setiap ide, prosedur, sistem, metode, konsep, prinsip, temuan atau data walaupun telah diungkapkan, dinyatakan, digambarkan, dijelaskan, atau digabungkan dalam sebuah Ciptaan.

c. Alat, benda, atau produk yang diciptakan hanya untuk menyelesaikan masalah teknis atau yang bentuknya hanya ditujukan untuk kebutuhan fungsional.
Tidak ada Hak Cipta atas hasil karya berupa:

a. Hasil rapat terbuka lembaga negara

b. Peraturan perundang-undangan

c. Pidato Kenegaraan atau pidato pejabat pemerintah

d. Putusan Pengadilan atau Penetapan Hakim dan

e. Kitab Suci atau simbol keagamaan.

\section{HAK EKONOMI BAGIAN DARI HAK CIPTA}

Di dalam Konstitusi kita yaitu Pasal 28H Ayat (4) UUD 1945 menyatakan"Setiap orang berhak mempunyai hak milik pribadi dan hak milik tersebut tidak boleh diambil alih sewenangwenang oleh siapapun". Ketentuan Pasal 28 H Ayat (4) UUD 1945 pasca reformasi ini mirip dengan rumusan Pasal 26 Ayat UUDS 1950, yaitu "Seorangpun tidak boleh dirampas dengan semena-mena". Namun dalam Pasal 26 Ayat (3) UUDS ini ditambahkan, "Hak milik itu adalah suatu fungsi sosial". Sedangkan dalam Pasal $28 \mathrm{H}$ UUD 1945 Pascareformasi, konsepsi hak milik yang berfungsi sosial itu tidak ada lagi. Dengan ketentuan bahwa hak milik pribadi tidak dapat diambil oleh siapapun, berarti konsepsi hak milik pribadi dalam UUD 1945 bersifat mutlak, kecuali atas ganti kerugian yang didasarkan atas 
transaksi yang bersifat sukarela. Penggantian kerugian juga harus ditentukan atas kesepakatan harga secara bersama. Dengan demikian dapat dikatakan bahwa konsepsi hak milik dalam UUD 1945 mengalami liberalisasi dengan meninggalkan unsur-unsur sosialisme dalam fungsi hak milik. ${ }^{31}$

Hak Cipta yang merupakan bagian dari Hak Milik Intelektual (Intellectual Property Rights) otomatis mengandung Hak Ekonomi di dalamnya karena dengan Ciptaannya tersebut Pencipta akan mendapatkan keuntungan atau menikmati keuntungan atas Ciptaannya. Dan tidak setiap orang bebas untuk menggunakan atau menikamati Ciptaan si Pencipta tersebut karena didalamnya ada nilai ekonomis yang diperoleh dari olah pikir si Pencipta sehingga Hak Cipta ini juga mengandung unsur-unsur liberalisme.

Hak Cipta terdiri atas Hak Ekonomi (economic rights) dan Hak Moral (moral rights). Hak Ekonomi adalah hak untuk mendapatkan manfaat ekonomi atas Ciptaan serta hak yang terkait. Hak Moral adalah hak yang melekat pada diri Pencipta atau Pelaku yang tidak dapat dihilangkan atau dihapus tanpa alasan apapun, walaupun Hak Cipta atau Hak Terkait telah dialihkan. ${ }^{32}$

\footnotetext{
${ }^{31}$ Jimly Asshiddiqie, Op.Cit, hal, 265.

${ }^{32}$ Kitab Undang-Undang HAKI (Hak Kekayaan Intelektual), Fokusmedia, Bandung, 2013, hal. 3.
}

Hak Ekonomi dapat juga diberi istilah dengan Financial Rights adalah hak yang dimiliki oleh seorang Pencipta untuk mendapatkan keuntungan atas Ciptaannya. Hak Ekonomi ini pada setiap UndangUndang Hak Cipta selalu berbeda, baik terminologinya, jenis hak yang meliputinya, maupun ruang lingkup dari tiap jenis Hak Ekonomi tersebut. Secara umum setiap negara minimal mengenal dan mengatur Hak Ekonomi tersebut meliputi jenis hak: ${ }^{33}$

a.Hak reproduksi atau penggandaan

b.Hak adaptasi

c. Hak distribusi

d. Hak pertunjukan

e. Hak penyiaran

f. Hak program kabel

g. Droit de suite (Hak yang mengikuti)

h. Hak pinjam masyarakat

a. Hak reproduksi atau penggandaan ${ }^{34}$

Hak Pencipta untuk menggandakan Ciptaannya, ini merupakan penjabaran dari Hak Ekonomi si Pencipta. Dalam istilah Undang-Undang Nomor 19 Tahun 2002 tentang Hak Cipta, Hak Reproduksi termasuk dalam pengertian "mengumumkan atau memperbanyak" sebagaimana yang dimaksud dalam Pasal 2 ayat (1) ${ }^{35}$. Dalam pengertian umum, reproduksi sama dengan

\footnotetext{
${ }^{33}$ Muhammad Djumhana, R.Djubaedillah, Op,Cit, 2014, hal 79.

${ }^{34}$ Ibid, hal. 79-80.

${ }^{35}$ Lihat lebih lanjut Pasal 2 Ayat (1) Undang-Undang Nomor 19 Tahun 2002 Tentang Hak Cipta 
perbanyakan, yaitu menambah jumlah suatu Ciptaan dengan pembuatan yang sama, atau menyerupai Ciptaan tersebut dengan mempergunakan bahan-bahan yang sama, termasuk mengalihwujudkan sesuatu Ciptaan. Hak reproduksi ini juga mencakup perubahan bentuk Ciptaan satu ke Ciptaan lainnya, misalnya, rekaman musik, pertunjukan drama, juga pembuatan duplikat dalam rekaman suara dan film.

b.Hak Adaptasi ${ }^{36}$

Hak untuk mengadakan adaptasi dapat berupa penerjemahan dari bahasa satu ke bahasa yang lain, aransemen musik, dramatisasi dari nondramatik, mengubah menjadi cerita fiksi dari karangan non fiksi, atau sebaliknya. Pengertian adaptasi pada uraian diatas pada dasarnya berupa modifikasi dari karya yang ada menjadi karya lainnya, sebagai hasil eksplorasi atas karya pertamanya dalam rangka mengeksploitasi potensi yang dimilikinya guna mendapatkan nilai tambah yang lebih besar.

c.Hak distribusi ${ }^{37}$

Hak distribusi adalah hak yang dimiliki Pencipta untuk menyebarkan pada masyarakat setiap hasil ciptaannya. Penyebaran tersebut dapat berupa bentuk penjualan, penyewaan, atau bentuk lain

\footnotetext{
${ }^{36}$ Muhammad Djumhana, R Djubaedillah, Op, Cit, 2014, hal. 81

${ }^{37}$ Ibid, hal. 82
}

yang dimaksudkan agar Ciptaan tersebut dikenal oleh masyarakat. Dalam hak ini termasuk pula bentuk yang tercantum dalam Undang-Undang Nomor 19 Tahun 2000 tentang Hak Cipta Pasal 2 ayat (1) "mengumumkan atau memperbanyak", termasuk kegiatan menerjemah, mengadaptasi, mengaransemen, mengalihwujudkan, menjual, menyewakan, meminjamkan, mengimpor, memamerkan, mempertunjukan kepada publik, menyiarkan, merekam, dan mengkomunikasikan Ciptaan kepada publik melalui sarana apapun.

d.Hak penampilan atau perfomance right. ${ }^{39}$

Hak ini dimiliki para pemusik, dramawan, ataupun seniman lainnya yang karyanya dapat terungkapkan dalam bentuk pertunjukan. Pengaturan tentang hak pertunjukan ini di kenal, baik dalam Konvensi Berne (Konvensi tentang perlindungan karya seni dan sastra) maupun Konvensi Universal, bahkan diatur tersendiri dalam sebuah Konvensi, yaitu Konvensi Roma (Konvensi untuk bidangbidang yang terkait dengan Hak

\footnotetext{
${ }^{38}$ Pasal 2 ayat (1) Undang-Undang Nomor 19 Tahun 2000 menyatakan bahwa Hak Cipta merupakan hak eksklusif bagi Pencipta atau Pemegang Hak Cipta untuk mengumumkan atau memperbanyak Ciptaannya yang timbul secara otomatis setelah suatu ciptaan dilahirkan tanpa mengurangi pembatasan menurut peraturan perundang-undangan. Yang dimaksud dengan hak eksklusif adalah hak yang sematamata diperuntukan bagi pemegangnya sehingga tidak ada pihak lain yang boleh memanfaatkan hak tersebut tanpa izin pemegangnya.

${ }^{39}$ Muhammad Djumhana, R Djubaedillah, Op, Cit, 2014, hal. 84
} 
Cipta/Neighbouring Rights, Related Rights).

Dengan pasti setiap perundang-undangan

Hak Cipta setiap negara akan mengaturnya.

Dalam Undang-Undang Hak Cipta ditentukan bahwa performing right adalah Hak Esklusif dan dilindungi selama 28 tahun. Menurut Copinger, "pendaftaran tidak diperlukan untuk mendapatkan perlindungan bagi hak pertunjukan ini. Peraturan yang berlaku sekarang di Inggris untuk mengatur Hak Pertunjukan ini adalah Performers Protection Act 1958 dan yang terakhir dikeluarkan tahun $1973 .{ }^{40}$ Yang dimaksud pertunjukan adalah termasuk untuk penyajian kuliah, pidato, khotbah, baik melalui visual maupun presentasi suara, juga menyangkut penyiaran film, dan rekaman suara pada media televisi, radio, dan tempat lain yang menyajikan tampilan tersebut ${ }^{41}$

e. Hak penyiaran (broadcasting right $)^{42}$

Hak untuk menyiarkan bentuknya berupa mentransmisikan suatu Ciptaan oleh peralatan tanpa kabel. Hak penyiaran ini meliputi penyiaran ulang dan mentransmisi ulang. Ketentuan hak ini telah diatur baik dalam Konvemsi Berne maupun Konvensi Universal, juga konvensi sendiri misalnya Konvensi Roma 1961 dan Konvensi Brussel

40 Ibid, hal 84 dikutip dari Copinger and Skone James, 1980, Copyright, Cetaka keduabelas, London: Sweet \&Maxwell, h.5000

${ }^{41}$ Ibid, hal. 84

${ }^{42}$ Ibid, hal. 88
1974 yang dikenal dengan Relating to the Distribution of Programme Carryng Signals Transmitted by Satelite. Hanya saja dibeberapa negara, hak penyiaran ini masih merupakan cakupan dari hak pertunjukan.

Menyiarkan sebagai bentuk hak tersendiri dari bagian hak ekonomi adalah suatu kegiatan dari pemilik hak cipta termasuk menyewakan, melakukan pertunjukan umum (public performance), mengkomunikasikan pertunjukan langsung (life perfomance), dan mengkomunikasikan secara interaktif suatu karya rekaman pelaku. Yang dimaksud dengan pelaku adalah aktor, penyanyi, pemusik, penari atau mereka yang menampilkan, memperagakan, mempertunjukan. Menyanyikan, menyampaikan, mendeklamasikan, atau memainkan suatu karya musik, drama, tari, sastra, folklore, atau karya seni lainya. ${ }^{43}$

\section{f. Hak program kabel ${ }^{44}$}

Hak ini hampir sama dengan hak penyiaran hanya saja mentransmisikannya melalui kabel. Dengan demikian, Pencipta atau Pemegang Hak Cipta tidak dapat berdiri sendiri dalam mengumumkan atau menggandakan Ciptaannya, mereka harus bekerja sama dengan lembaga/badan penyiaran. Badan Penyiaran televisi mempunyai suatu studio tertentu, dari sana

${ }^{43}$ Lihat Pasal 1 angka 10 Undang-Undang Nomor 19 Tahun 2000 tentang Hak Cipta.

${ }^{44}$ Muhammad Djumhana, R Djubaedillah, Op, Cit, 2014, hal. $89-90$ 
disiarkan program-program melalui kabel kepada pesawat pelanggan. Jadi, siarnya sudah pasti bersifat komersil.

g. Droit de suite ${ }^{45}$ (Hak Mengikuti artinya hak itu terus mengikuti bendanya dimanapun juga (dalam tangan siapapun juga ) benda itu berada .

Adalah hak yang dimilki oleh Pencipta. Hak ini mulai diatur dalam Pasal 14 bis Konvensi Berne revisi Brussel 1948 yang kemudian ditambah lagi dengan Pasal 14 hasil revisi Stockholm 1967. Ketentuan Droit de suite ini menurut petunjuk dari WIPO (World Intellectual Property Organization) yang tercantum dalam buku Guide to the Berne Convention merupakan hak tambahan, Hak ini bersifat kebendaan.

h. Hak pinjam masyarakat atau public lending right ${ }^{46}$

Hak ini dimiliki oleh Pencipta yang karyanya tersimpan diperpustakaan, yaitu dia berhak atas suatu pembayaran dari pihak tertentu karena karya yang diciptakannya sering dipinjam oleh masyarakat dari perpustakaan milik pemerintah tersebut.

Dimanakah Hak Ekonomi ini diatur yang merupakan bagian dalam Hak Cipta? Hal ini dijelaskan dalam Undang-Undang Nomor 28 Tahun 2014 bahwa pengaturan tentang Hak Cipta mengandung Hak
Ekonomi terdapat dalam Pasal 8, 9,10. $11,12,13,14,15$.

Pasal 8:

Hak Ekonomi merupakan Hak Eksklusif Pencipta atau Pemegang Hak Cipta untuk mendapatkan manfaat ekonomi atas Ciptaannya

Pasal 9:

1, Pencipta atau Pemegang Hak Cipta sebagaimana yang dimaksud dalam Pasal 8 memiliki Hak Ekonomi untuk melakukan:

a. Penerbitan Ciptaan

b. Penggandaan Ciptaan dalam segala bentuknya

c. Penerjemahan Ciptaan

d. Pengadaptasian, pengaransemenan, atau pentransformasian Ciptaan

e. Pendistribusian Ciptaan atau salinannya

f. Pertunjukan Ciptaan

g. Pengumuman Ciptaan

h. Komunikasi Ciptaan

i. Penyewaan Ciptaan

2. Setiap orang yang melaksanakan Hak Ekonomi sebagaimana yang dimaksud pada ayat (1) wajib mendapatkan izin Pencipta atau Pemegang Hak Cipta

3. Setiap orang yang tanpa izin Pencipta atau Pemegang Hak Cipta dilarang melakukan Penggandaan dan/atau Penggunaan secara Komersil Ciptaan Pasal 10:

${ }^{45}$ Ibid, hal. 90

${ }^{46} \mathrm{Ibid}, \mathrm{hal}, 90$ 
Pengelola tempat perdagangan dilarang membiarkan penjualan dan/atau penggandaan barang hasil pelanggaran Hak Cipta dan/atau Hak yang terkait ditempat perdagangan yang dikelolanya.

Pasal 11:

1. Hak Ekonomi untuk melakukan pendistribusian Ciptaan atau salinan sebagaimana yang dimaksud dalam Pasal 9 ayat (1) huruf e tidak berlaku terhadap Ciptaan atau salinan yang telah dijual atau yang telah dialihkan kepemilikan Ciptaan kepada siapapun.

2. Hak Ekonomi untuk menyewakan Ciptaan atau salinannya sebagaimana yang dimaksud dalam Pasal 9 ayat (1) huruf i tidak berlaku terhadap program komputer dalam hal ini program komputer tersebut bukan merupakan objek esensial dari penyewaan.

Pasal 12:

1. Setiap orang dilarang melakukan penggunaan secara komersial, penggandaan, pengumuman, pendistribusian, dan/atau Komunikasi atas potret yang dibuatnya guna kepentingan reklame atau periklanan secara komersial tanpa persetujuan dari orang yang dipotret atau ahli warisnya.

2. Penggunaan secara komersial, penggandaan, pengumuman, pendistribusian, dan/atau Komunikasi
Potret sebagaimana yang dimaksud dalam ayat (1) yang memuat 2 orang atau lebih, wajib meminta persetujuan dari orang yang ada dalam Potret atau ahli warisnya.

Pasal 13:

Pengumuman, Pendistribusian, atau Komunikasi Potret seorang atau beberapa orang Pelaku Pertunjukan dalam suatu pertunjukan umum tidak dianggap sebagai pelanggaran Hak Cipta, kecuali dinyatakan lain atau diberi persetujuan oleh Pelaku Pertunjukan atau pemegang hak atas pertunjukan tersebut sebelum atau pada saat pertunjukan berlangsung.

Pasal 14:

Untuk kepentingan keamanan, kepentingan umum, dan/atau kepentingan proses peradilan pidana, instansi yang berwenang dapat melakukan Pengumuman, Pendistribusian atau Komunikasi Potret tanpa harus mendapatkan persetujuan dari seorang atau beberapa orang yang berada dalam Potret.

Pasal 15:

1.Kecuali diperjanjian lain, pemilik dan/atau pemegang Ciptaan fotografi, lukisan, gambar, karya arsitektur, patung, atau karya seni lain berhak melakukan pengumuman Ciptaan 
dalam suatu pameran umum atau Penggandaan dalam suatu katalog yang diproduksi untuk keperluan pameran tanpa persetujuan Pemcipta.

2. Ketentuan Pengumuman Ciptaan sebagaimana yang dimaksud pada ayat (1) berlaku juga terhadap Potret sepanjang tidak bertentangan dengan ketentuan sebagaiman yang dimaksud dalam Pasal 12.

Apakah Hak Ekonomi yang terdapat di dalam Hak Cipta dapat dialihkan? Ketentuan ini diatur dalam Pasal 16, 17 18 dan 19 Undang-Undang Nomor 28

Tahun 2014:

Pasal 16:

1. Hak Cipta merupakan Benda bergerak tidak berwujud

2. Hak Cipta dapat beralih atau dialihkan, baik seluruh maupun sebagian kerena:

a. Pewarisan

b. Hibah

c. Wakaf

d. Wasiat

e. Perjanjian tertulis

f. Sebab lain yang dibenarkan sesuai dengan ketentuan peraturan perundangundangan

3. Hak Cipta dapat dijadikan objek jaminan fidusia.
4. Ketentuan mengenai Hak Cipta sebagai objek jaminan fidusia sebagaimana yang dimaksud pada ayat (3) dilaksanakan sesuai dengan peraturan perundang-undangan.

Pasal 17:

1. Hak Ekonomi atas suatu Ciptaan tetap berada di tangan Pencipta atau Pemegang Hak Cipta selama Pencipta atau Pemegang Hak Cipta tidak mengalihkan seluruh Hak Ekonomi dari Pencipta atau Pemegang Hak Cipta tersebut kepada penerima pengalihan hak atas Ciptaan.

2. Hak Ekonomi yang dialihkan Pencipta atau Pemegang Hak Cipta untuk seluruh atau sebagian tidak dapat dialihkan untuk keduakalinya oleh Pencipta atau Pemegang Hak Cipta yang sama.

Pasal 18:

Ciptaan buku, dan/atau semua hasil karya tulis lainnya, lagu dan/atau musik dengan atau tanpa teks yang dialihkan dalam perjanjian jual putus dan/atau pengalihan tanpa batas waktu, Hak Ciptanya beralih kembali kepada Pencipta pada saat perjanjian tersebut mencapai jangka waktu 25 (dua puluh lima tahun)

Pasal 19: 
1. Hak Cipta yang dimilki Pencipta yang belum, telah, atau tidak dilakukan Pengumuman, Pendistribusian, atau Komunikasi setelah Penciptanya meninggal dunia menjadi milik ahli waris atau milik penerima wasiat.

2. Ketentuan sebagaimana dimaksud pada ayat (1) tidak berlaku jika hak tersebut diperoleh secara melawan hukum.

\section{KESIMPULAN}

Dari uraian diatas dapatlah penulis menyimpulkan bahwa Hak Cipta otomatis atau secara tidak langsung memunculkan Hak Ekonomi bagi Pencipta karena Hak Cipta memberikan keuntungan finansial bagi Penciptanya. Disamping itu juga orang lain yang akan menggunakan Ciptaan Pencipta harus terlebih dahulu mendapatkan izin dari Pencipta dan dia harus memberikan Royalty atau Technical Fee kepada Pencipta. Dengan demikian si Pencipta tentu mendapatkan keuntungan dari Royalty atau Technical Fee tersebut. Hasil Ciptaan Pencipta harus memiliki manfaat serta berguna secara ekonomi bagi masyarakat untuk menunjang kehidupan manusia sehingga Hak Ekonomi yang terkandung di dalam Hak Cipta tersebut tidak hanya menguntungkan pribadi bagi Penciptanya saja tetapi juga mempunyai manfaat ekonomi bagi masyarakat luas. Hak Ekonomi tersebut dapat berupa; hak reproduksi atau penggandaan, hak adaptasi, hak distribusi, hak penampilan atau peformance right, hak penyiaran, hak program kabel, droit de suite (hak yang mengikuti) dan hak pinjam masyarakat atau public lending rights.

Di dalam Undang-Undang Nomor 28 Tahun 2014 tentang Hak Cipta tegas-tegas telah dinyatakan juga bahwa: Pencipta atau Pemegang Hak Cipta sebagaimana yang dimaksud dalam memiliki hak ekonomi untuk melakukan:

a. Penerbitan Ciptaan

b. Penggandaan Ciptaan dalam segala bentuknya

c. Penerjemahan Ciptaan

d. Pengadaptasian, pengaransemenan, atau pentransformasian Ciptaan

e. Pendistribusian Ciptaan atau salinannya

f. Pertunjukan Ciptaan

g. Pengumuman Ciptaan

h. Komunikasi Ciptaan

i. Penyewaan Ciptaan

\section{DAFTAR PUSTAKA}

Asshiddiqie, Jimly, Konstitusi Ekonomi, Penerbit KOMPAS, Jakarta, 2010 
Asyhadie, Zaeni, Hukum Bisnis Prinsip dan Pelaksanaanya di Indonesia, Rajawali Pers, Jakarta, 2012.

Direktoral Jenderal Hak Kekayaan Intelektual, Buku Panduan Hak Kekayaan Intelektual, Tangerang, 2005

Djumhana, Muhammad dan Djubaedillah, R, Hak Milik Intelaktual Sejarah, Teori dan Praktiknya di Indonesia, PT.Citra Aditya Bakti, Bandung, 2014

HS, Salim, Pengantar Hukum Perdata Tertulis $(B W)$, Sinar Grafika, Jakarta, 2005

Nasution, Rahmi Jened Parinduri, Interface Hukum Kekayaan Intelektual dan Hukum Persaingan (Penyalahgunaan HKI), Rajawali Pers, Jakarta, 2013

Saidin, H. OK, Aspek Hukum Hak Kekayaan Intelektual (Intellectual Property Rights), Rajawali Pers, Jakarta, 2004

Soekamto, Soerjono, Pengantar Penelitian Hukum, UI Press, Jakarta, 1986.

Suratman, Philips Dillah, Metode Penelitian Hukum, Alfabeta, Bandung, 2012.

Undang-Undang Nomor 19 Tahun 2002 tentang Hak Cipta

Undang-Undang Nomor 28 Tahun 2014 tentang Hak Cipta

Kitab Undang-Undang HaKI (Hak Kekayaan Intelektual), Fokusmedia, Bandung, 2013

Kitab Undang-Undang Hukum Perdata (KUH Perdata) 